\title{
INDUCES OF ANTIOXIDANT COMPOUNDS AND SALT TOLERANCE IN WHEAT PLANT, IRRIGATED WITH SEAWATER AS RESPONSE TO APPLICATION OF MICROALGAE SPRAY
}

\author{
${ }^{1}$ Hanaa H. Abd El Baky, ${ }^{2}$ M.M. Hussein and ${ }^{3}$ Gamal S. El-Baroty \\ ${ }^{1}$ Department of Plant Biochemistry, National Research Centre, Dokki, Cairo, Egypt \\ ${ }^{2}$ Department of Water Relations and Irrigation, National Research Centre, Dokki, Cairo, Egypt \\ ${ }^{3}$ Department of Biochemistry, Faculty of Agriculture, Cairo University, Egypt
}

Received 2013-12-05; Revised 2013-12-17; Accepted 2014-01-07

\begin{abstract}
Wheat plants (Triticum aestivum L., cv. Giza 168) irrigated with either 10 or $20 \%$ of Seawater (SW) were treated with aqueous extracts of green microalgae Scenedesmus obliquus and blue green algae Spirulina platensis (AESO and AESP $20 \mathrm{~g}$ (dry weight)/L) in order to increase wheat salt tolerance. Treated plants showed higher ability to tolerate salt stress $(10$ or $20 \%$ SW) by significant $(\mathrm{p}>0.5 \%)$ increasing of photosynthetic pigments (chlorophyll: Chlorophyll total, chlorophyll a and b types) and antioxidant lowmolecular compounds (glutathione and carotenoids) contents. The increase of these contents was associated with increasing activities of antioxidant enzyme systems Superoxide Dismutase (SOD), Ascorbate Peroxidase (APX), Catalase (CAT) and total Peroxidase (POD). In addition, this observation was significantly correlated with decreasing of lipid peroxide products (TBARs) and sodium ions concentrations. However, wheat plant exposed to salt stress showed significant changes in all growth parameter and antioxidant low-molecular compounds and antioxidant enzyme activities compared with that in plants irrigated with regular water (tap water). In addition, plants treated with oxalic acid as bioregulator agent implied a moderate changes on growth parameters, antioxidant capacity includes non-enzyme and enzymatic systems compared with that in wheat plants treated with algae extracts. This study indicates that the algae extracts could be used as a promising plant growth enhancer for treating wheat plants irrigated with brackish water.
\end{abstract}

Keywords: Microalgae Scenedesmus Obliquus, Spirulina Platensis, Antioxidants, Oxalic Acid, Salt Tolerance, Antioxidant Enzymes System, Irrigation with Seawater and Wheat Plants

\section{INTRODUCTION}

The Reactive Oxygen Species (ROS) comprises both free radical $\left(\mathrm{O}^{-2}\right.$, superoxide radicals; $\mathrm{OH}^{-}$, hydroxyl radical; $\mathrm{HO}^{2-}$, perhydroxy radical $\mathrm{ROO}^{2}$-and alkoxy radicals $\left.\mathrm{RO}^{-}\right)$and non-radical forms $\left(\mathrm{H}_{2} \mathrm{O}_{2}\right.$, hydrogen peroxide and ${ }_{1} \mathrm{O}^{2}$, singlet oxygen) are produced in plants under normal growth conditions and their concentration were low, while under stressful environments it is considerably high (Polle, 2001). However, exposure of Corresponding Author: Hanaa H. Abd El Baky, Department of Plant Biochemistry, National Research Centre, Dokki, Cairo, Egypt

plants to unfavorable environmental conditions such as temperature extremes, heavy metals, drought, nutrient deficiency, or salt stress, can induce increase the production of ROS (Karpinski et al., 2003; Laloi et al., 2004; Gill and Tuteja, 2010). In stomata closure, osmotic stress leads to leak in $\mathrm{CO}_{2}$ availability for photosynthetic carbon assimilation, thereby causing high accumulation of superoxide in chloroplast which can cause photoinhibition and photo-oxidation damages (Ashraf et al., 2008). Under pathogens, drought and salinity stress 
condition; ROS are generated through pathways such as photorespiration, mitochondrial respiration and from the photosynthetic apparatus (Pei et al., 2000). However, under these conditions, the cellular electron transport within the different subcellular compartments is impairs and lead to generation of ROS compounds (Ali and Alqurainy, 2006). Therefore, ROS could be considered as cellular biomarker for stresses and as secondary messenger in the stress response signaling pathways. However, plants have the high ability to scavenge ROS radicals by producing two types of antioxidants action includes: Enzymatic and non-enzymatic systems (Abd El Baky et al., 2010; Gupta et al., 1999). Enzymatic antioxidants include Superoxide Dismutase (SOD), Catalase (CAT), Ascorbate Peroxidase (APX), Peroxidase (POD) and Glutathione Reductase (GR). Whereas, nonenzymatic antioxidant includes (low molecular weight): Glutathione (GSH), Ascorbate (AsA), carotenoids and phenolic compounds (Asada, 1999; Kiddle et al., 2003).

Microalgae are one of the potential organisms and useful to mankind in various ways: Marine culture, food, feed, fuel, medicine, industry and in combating pollution (Thajuddin and Subramanin, 2005; Abd El-Baky and ElBaroty, 2012). Also, it is conceder as a rich source of several fine chemicals of economic value such as vitamins, carotenoids, phycobiliprotein, polysaccharides, fatty acids which possess varied biological properties and showed antibacterial, antifungal, antioxidant, anticancer and immune modulator agents (Abd El Baky et al., 2012; Abd El Baky and El-Baroty, 2013a). In the agriculture and horticulture field, microalgae exhibited stimulate action to growth of plants and can enhanced the plant to tolerate the a biotic stress, due to the presence of auxine, cytokinins, gibberellins, other related growth regulators and antioxidant compounds (Ordog et al., 2004; Molnar and Ordog, 2005; Abd El Baky et al., 2010). However, many studies indicated that some natural compounds might play an important role in enhancing plant tolerance to some abiotic stresses such as salt, drought and extreme temperatures (Ashraf, 2010; Abd El Baky et al., 2010). However, a positive association between the high accumulation of antioxidants and degree of salt tolerance has been drawn in different plant species. As examples, guaiacol Peroxidase (POX), SOD, POX and CAT enzyme activities play a significant role in the protection and recovery of several plants against oxidative stress induced by salt stress (Ashraf, 2010; Turhan et al., 2008). Moreover, plants contain a variety of nonenzymatic molecules (ascorbic acid, tocopherols, carotenoids, flavonoids, glutathione) which play a substantial role in counteracting oxidative stress caused by stresses (Tausz et al., 2000; Schafer et al., 2002). Abd El Baky et al. (2010), reported that microalgae could be enhanced plant salt tolerance through increasing the production of non-antioxidant compounds and elevate the activities of antioxidant enzyme system. Since, evaluation of functioning of all natural components in salt tolerance including that of oxidative stress tolerance is necessary. Therefore, this study was aimed to understand the impact of treated wheat plants irrigated with 10 and $20 \%$ seawater with algal extracts as bioregulator to enhance salt tolerance.

\section{MATERIALS AND METHODS}

\subsection{Algal Strains and Growth Conditions}

Scenedesmus obliquus and Spirulina platensis algae were grown in $30 \mathrm{~L}$ medium containing $10 \mathrm{ppm}$ (NSI media) and $51 \mathrm{ppm}$ (Zarriuk media), respectively as stress $\mathrm{N}_{2}$ concentration in order to induction antioxidant compounds. All culture flasks were illuminated by continuous cool white fluorescent lamps (Philips at $200 \mathrm{~W} \mathrm{~m}^{-2}$ as optimum illumination conditions) as reported by Abd El Baky et al. (2012) and Abd El-Baky and El-Baroty (2012).

\subsection{Plant Materials}

Wheat cultivar named Giza 168 was obtained from Wheat Department, Agriculture Research Center, Giza, Egypt.

\subsection{Cultivation of Wheat}

A pot experiment was conducted in the greenhouse of National Research Centre Dokki, Cairo, Egypt during 2012/2013 winter season in order to evaluate the effect of spraying foliar of two algal strains (Scenedesmus obliquus and $S$. platensis) extracts $\left(20 \mathrm{~g} \mathrm{~L}^{-1}\right.$ dry weight in $0.1 \%$ Tween solution) as biofertillizer and sources of growth promoter to enhance salt tolerance of wheat plant irrigated with 10 and $20 \%$ sea water in tap water. Also, wheat plants irrigated with tap water were used as control plants. Organic acid (Oxalic acid $200 \mathrm{mg} \mathrm{L}^{-1}$ ) was used as positive control plants. The experimental design was split plot (each 6 replicates). Salt stress treatments were started at 57 days from cultivation where plants irrigated by saline water and in next irrigation followed by tap water alternatively until the end of experiment. Samples from treated plants were taken at 70 days from sowing for chemical analysis. At the same time the plant received the optimum fertilizer $\left(\mathrm{PO}_{4}^{-}, \mathrm{K}^{+}\right.$and $\mathrm{N}$ as recommended by Agriculture of Ministry in Egypt). 


\subsection{Extraction and Determination of Antioxidant in Algal cells Wheat Leaves}

\subsubsection{Extraction of Carotenoids and Tocopherols}

Carotenoid and tocopherol compounds were extracted from freshly plant material with 1: $10(\mathrm{w} / \mathrm{v})$ Tetrahydrofuran (THF) in present $30 \mathrm{mg}^{-1}$ of BHT $(2,6-$ ditertra-butyl-p-cresol) and magnesium carbonate (1 g 10 $\mathrm{g}^{-1}$ sample). After $24 \mathrm{~h}$, an aliquot of the clear extracted pigments was filtered and evaporated to $5 \mathrm{~mL}$ using a stream of $\mathrm{N}_{2}$ gas. The extracted pigments were saponified with $25 \mathrm{~mL}$ of ethanolic $\mathrm{KOH}(10 \%)$, for $2 \mathrm{~h}$ at room temperature and then carotenoids and tocopherols were extracted with dichloromethane. The solvent layer was then separated, washed several times with distilled water, dried over $\mathrm{Na}_{2} \mathrm{SO}_{4}$ and complete dryness was attained by a stream of nitrogen (Abd El Baky and El-Baroty, 2013b).

Determination of algal total carotenoids: The total carotenoids were determined by spectrophotometric method at $450 \mathrm{~nm}$. Bcarotene served as a standard compound, was used for preparing the calibration curve (Semeneko and Abdullaev, 1980).

\subsection{Extraction and Determination of Ascorbic Acid}

Ascorbic acid (vitamin C) was extracted from the plant material with $2 \%$ metaphosphoric acid and determined by spectrophotometrically using 2,6 dichlorophenol indophenol dye (Augustin, 1985).

\subsection{Determination of Total Phenolics}

Total phenolic content was determined by the FolinCiocalteu method (Li et al., 2007). In brief, $1 \mathrm{~mL}$ of 1:10 diluted Folin-Ciocalteu reagent were added to $200 \mu \mathrm{L}$ aliquot of extract, after $4 \mathrm{~min}, 800 \mu \mathrm{L}$ of saturated sodium carbonate $\left(75 \mathrm{~g} \mathrm{~L}^{-1}\right)$ was added. The mixture was incubated for $2 \mathrm{~h}$ at $25^{\circ} \mathrm{C}$ and then the absorbance was measured at $765 \mathrm{~nm}$. Gallic acid $\left(0-500 \mathrm{mg} \mathrm{L}^{-1}\right)$ was used for preparation of standard calibration curve. The results were expressed as gallic acid equivalent $(\mathrm{GAE}) / \mathrm{g}$ dry weight and calculated as mean value $\pm \operatorname{SD}(n=3)$.

\subsection{Extraction and Estimation of Chlorophyll}

One gram of wheat leaves (FW) dried on filter paper, was ground in acetone $(5 \mathrm{~mL}, 80 \%)$ and allowed to stand overnight in dark at $4^{\circ} \mathrm{C}$ followed by centrifugation at $10,000 \times \mathrm{g}$ for $5 \mathrm{~min}$. The contents of total Chlorophyll (T-Chl), Chlorophyll a (Chl-a) and
Chlorophyll b (Chl-b) in the supernatant were determined according to Lichtenthaler (1987).

\subsection{Preparation of Cytosolic Fraction}

Five grams leaves of wheat were excised and homogenized in $5 \mathrm{~mL}$ of ice-cold grinding buffer (250 $\mathrm{mM}$ sucrose, $25 \mathrm{mM}$ Tris and the $\mathrm{pH}$ was adjusted to 7.2). The homogenate was centrifuged at $12000 \times \mathrm{g}$ for 15 $\min$ at $4^{\circ} \mathrm{C}$. The resulting supernatant was used for analyses of antioxidant enzyme activities, GSH, lipid peroxidation and protein content.

\subsection{Determination of Glutathione (GSH)}

The GSH contents of algal cells and wheat extracts were measured by reaction with 5,5 Dithiobis -2Nitrobenzoic (DTNB) reagent to give a compound that absorbed at $412 \mathrm{~nm}$ (Silber et al., 1992).

\subsection{Enzymes Assays}

The activity of cytosolic SOD (EC 1.15.1.1) was determined by photochemical method (Ginnopolitis and Ries, 1977). Spectrophotometrically estimated as described by Chance and Maehly (1955) was used to assay the POD activity (EC 1.11.1.7). Ascorbate Peroxidase (APX) (EC 1.11.1.11) was determined according to Nakano and Asada (1981).

\subsection{Determination of Lipid Peroxidation Products}

The lipid peroxidation products was estimated by the formation of Thiobarbaturic Acid Reactive Substances (TBARS) and quantified in term of Malonaldhyde (MDA) as described by Haraguchi et al. (1997). The lipid peroxidation was expressed as micromoles of MDA. The extinction coefficient of TBARS was taken as $1.56 \times 10^{5}$ at $532 \mathrm{~nm}$.

\subsection{Determination of Proteins}

Protein concentration of cytosol was determined spectrophotometrically at $595 \mathrm{~nm}$, using comassein blue G 250 as a protein binding dye (Bradford, 1976). Bovine Serum Albumin (BSA) was used as a protein standard.

\subsection{Estimation of Growth and Grain Yield}

Nine plants from each treatment (three plants per replicate) were collected and immediately rinsed with iso-osmotic solution, blotted on filter paper and weighed to obtain the Fresh Weight (FW). For determination of Dry Weight (DW) the plant parts from each treatment dried to a constant weight at $65^{\circ} \mathrm{C}$. Leaves and stems 
were separated and weighed. After harvest, the weight of 100 grains and grain yields were calculated.

\subsection{Statistical Analysis}

Results were statistically analyzed by Snedecor and Cochran (1989).

\section{RESULTS}

\subsection{Total Antioxidant Content of Algal Extracts}

According to our previous study, microalgae could be grown under nitrogen limitation in order to enhance biosynthesis some fine biomolecules (Abd El Baky and El-Baroty, 2013a). Thus, S. obiuuqs and S. platensis were cultured in nitrogen deficient media for induction of antioxidant compounds in algal cells and the data are presented in Table 1. The results revealed that the both algal cells showed significant increase in antioxidant molecule when compared with algae grow in medium containing optimum nitrogen levels (data not shown).

However, the concentrations of Ascorbic Acid (AA), Total Carotenoids (T-CAR), tocopherols, phycocyanin, GSH, Total Flavonoids (TFC) and Total Phenolic (TPCs) in algal $S$. obliquus and $S$. platensis (in parentheses) grown under nitrogen stress (nitrogen deficient) were 2.33 (1.28\%), 4.54 (1.65\%), 1.02 (0.43\%), 0.0 (13.51\%), $0.321(0.245 \mathrm{mM}), 0.94(0.87 \%)$ and $1.43(1.73)$, respectively. These values revealed that $S$. obliquus was characterized by high content of AA and TCO than that found in $S$. platensis with about 2 and 3 times, respectively. On contrary, S. platensis was contained much high amounts of phycocynine blue pigments, while S. obliquus did not contain this pigment.

\subsection{Effect of Algal Extracts on Photosynthetic Pigment Contents of Wheat Plants Cultivated Under Sea Water Stress}

The concentration of photosynthetic pigments of wheat plants irrigated sea water (10 and $20 \%$, SW) are shown in Table 2. In general, wheat plants irrigated with SW showed significant decreases in the amounts of T-Chl and Chl-a and Chl-b contents when compared with wheat plants irrigated Regular Water (RW). For example, T-Chl contents in wheat plant irrigated 10 and $20 \%$ (v/v) SW were 0.652 and $0.597 \mathrm{mg} \mathrm{g}^{-1} \mathrm{FW}$, respectively. Whereas the value was $0.822 \mathrm{mg} \mathrm{g}^{-1} \mathrm{FW}$, in plants irrigated with RW only. Thus, chlorophyll degradation was dependant on water salinity level. Application of algal S. obliquus and S. platensis extracts to wheat plants irrigated SW led to significant increase in the concentrations of T-Chl, Chla and Chl-b as compared with the values of plants irrigated SW only. The T-Chl content was ranged from 0.903 to $1.037 \mathrm{mg} \mathrm{g}^{-1}$ and 0.698 to $0.0721 \mathrm{mg} \mathrm{g}^{-1} \mathrm{FW}$ in wheat plants irrigated with $10 \%$ and $20 \%$ (v/v) SW and treated with algal $S$. obliuues and $S$. platensis extracts. While, in non-treated plants, these values were 0.652 and $0.597 \mathrm{mg} \mathrm{g}^{-1}(\mathrm{FW})$, respectively. In similar trend for photo-synthetic pigments, T-Chl, Chl-a and Chl-b contents, were observed in plants treated with oxalic acid as a plant growth factor.

However, this increase was less pronounced, when compared with that induced in wheat stressed plant treated with algal extracts. Thus, the level of photosynthetic pigment was found to be restored in treated wheat plants irrigated SW due to application of algal extracts.

\subsection{Effect of Algal Extracts on Antioxidant Status of Wheat Plants Cultivated Under Sea Water Stress}

As shown in Table 3, irrigation of wheat plants with 10 and $20 \%$ (in parenthesis) SW caused significantly increase in the accumulation of antioxidant compounds including: TCAR, TOC, AA, TPCs and GSH in wheat plants over than that in plant irrigated RW only (Table 3). The levels of these compounds were about 1.3 (1.5), 1.2 (1.5), 1.5 (2.2), 1.2 (1.4) and 1.1 (1.7) times as great as that in wheat plants irrigated RW, respectively.

Application of algal extracts of S. platensis and $S$. obliquues contained high level of antioxidants constituents on wheat plants irrigated $10 \% \mathrm{SW}$, led to significant increase in antioxidant molecules including: T-CAR, TOC, AA, TPCs and GSH with values being about 2.3 (1.9), 3.3 (2.9), 2.7 (2.4), 1.4 (1.3) and 2.9 (2.3) as greater as that in non-treated plants (irrigated with $10 \% \mathrm{SW}$, only), respectively. In plant irrigated $20 \% \mathrm{SW}$, these values were about 2.2 (1.9), 2.4 (2.0), 2.2 (1.8), 1.3 (1.3) and 2.32 (1.8) as high as that in plants irrigated with $20 \% \mathrm{SW}$, respectively. According to these values, it could be demonstrated that the antioxidant contents in wheat plants irrigated with sea water were positively correlated with the levels of total antioxidant in algae extracts. As compared with foliar application of growth bioregulator oxalic acid (plant growth regulator), the both algal extracts caused great increase in antioxidant compounds in wheat plant irrigated sea wheat. The $\mathrm{CAR}$ and $\mathrm{TOH}$ contents were slightly increased under salt-stress. This increase was significantly higher than that of negative control plants, but was similar to that in plant treated with bioregulator. 
Hanaa H. Abd El Baky et al. / American Journal of Agricultural and Biological Sciences 9 (2): 127-137, 2014

Table 1. Antioxidant contents of Spirulina platensis and Scenedesmus obliquus grown under stress conditions

\begin{tabular}{lcc}
\hline Compound & Spirulina platensis & Scenedesmus obliquus \\
\hline Ascorbic acid (\%) & 1.280 & 2.330 \\
Carotenoids (\%) & 1.650 & 4.540 \\
Tocopherols (\%) & 0.430 & 1.020 \\
Phycocyanin (\%) & 13.510 & 0.000 \\
GSH (mM) & 0.245 & 0.321 \\
Total flavonoids (\%) & 0.870 & 0.940 \\
Total phenolic (\%) & 1.730 & 1.430 \\
\hline
\end{tabular}

Table 2. Influences of Spirulina platensis and Scenedesmus obliquus extracts spraying on chlorophyll contents of wheat levies irrgated by diluted sea water

\begin{tabular}{|c|c|c|c|c|c|c|c|c|}
\hline Salinity & Treatments & $\begin{array}{l}\text { Chl a } \\
\mathrm{mg} / \mathrm{g} \text { f.w }\end{array}$ & $\begin{array}{l}\text { Chl b } \\
\text { mg/g f.w }\end{array}$ & $\begin{array}{l}\text { Tatal Chl. } \\
\text { mg/g f.w }\end{array}$ & Ratio $^{a}$ & Ratio $^{\mathrm{b}}$ & Ratio $^{c}$ & $\mathrm{Chl} \mathrm{a/Chl} \mathrm{b}$ \\
\hline \multirow[t]{4}{*}{ Tap water } & $\begin{array}{l}\text { Negative control } \\
\text { (without only spraying) }\end{array}$ & 0.452 & 0.17 & 0.622 & 0.0 & & & 2.66 \\
\hline & Sp. & 0.997 & 0.19 & 1.100 & 1.8 & 2.4 & 3.0 & 3.7 \\
\hline & Sc. & 0.721 & 0.17 & 0.891 & 1.4 & 2.0 & 2.4 & 3.1 \\
\hline & $\begin{array}{l}\text { Positive control } \\
\text { (Oxalic acid) }\end{array}$ & 0.539 & 0.18 & 0.719 & 1.1 & 1.6 & 2.0 & 3.0 \\
\hline \multirow[t]{4}{*}{$10 \%$ sea water } & $\begin{array}{l}\text { Negative control } \\
\text { (without only spraying) }\end{array}$ & 0.321 & 0.13 & 0.451 & 0.7 & 0.0 & & 2.5 \\
\hline & Sp. & 0.530 & 0.16 & 0.690 & 1.1 & 1.5 & 1.9 & 3.3 \\
\hline & Sc. & 0.533 & 0.15 & 0.683 & 1.1 & 1.5 & 1.9 & 5.4 \\
\hline & $\begin{array}{l}\text { Positive control } \\
\text { (Oxalic acid) }\end{array}$ & 0.491 & 0.17 & 0.691 & 1.1 & 1.5 & 1.9 & 2.9 \\
\hline \multirow[t]{4}{*}{$20 \%$ sea water } & $\begin{array}{l}\text { Negative control } \\
\text { (without only spraying) }\end{array}$ & 0.255 & 0.11 & 0.365 & 0.6 & 0.8 & 0.0 & 2.3 \\
\hline & Sp. & 0.501 & 0.15 & 0.651 & 1.0 & 1.4 & 1.8 & 3.3 \\
\hline & sc. & 0.695 & 0.21 & 0.860 & 1.4 & 2.0 & 2.4 & 3.3 \\
\hline & $\begin{array}{l}\text { Positive control } \\
\text { (Oxalic acid) }\end{array}$ & 0.431 & 0.17 & 0.601 & 1.0 & 1.3 & 1.6 & 2.5 \\
\hline LSD at $(=<0.05)$ & & 0.11 & 0.01 & 0.210 & & & & \\
\hline
\end{tabular}

Ratio $^{\text {b: }}$ Treatment/Negative control (without only spraying and irrigated by $10 \%$ sea water); Ratio ${ }^{\text {c }}$ : Treatment/Negative control (without only spraying and irrigated by $20 \%$ sea water)

In contrast, foliar application of algal extract significant increased antioxidant content in wheat plants grown under low and high SW water levels over than of wheat plants treated with bioregulator. Similar trend was reported in the literature for increased levels of $\mathrm{AA}, \mathrm{PhOH}$ and $\mathrm{GSH}$ in plants grown under stress conditions. For instance, ascorbic acid as one of the two major soluble antioxidants in chloroplast, possess a photoprotective function due to it is antioxidant capacity.

\subsection{Antioxidant Enzyme Activities}

The change in antioxidant enzyme activities of SOD, POD, APX and CAT (enzyme activity was expressed on a protein basis, specific activity) in wheat leaves was significantly $(\mathrm{p} \leq 0.05)$ affected by irrigation of $\mathrm{SW}$ (Table 4). The SOD enzyme activity in wheat plants was increased with an increase of $10 \%$ and $20 \%$ SW levels, with values of 41.21 and $49.29 \mathrm{U} \mathrm{mg}^{-1}$ protein/min, respectively. While, this value was $34.22 \mathrm{U} \mathrm{mg}^{-1}$ protein/min in plant irrigated RW. Treated 10 and $20 \%$ SW wheat plant with algal extracts of $S$. obliquues and $S$. platensis (in parenthesis) had high SOD activity with values 49.31 (51.52) and 53.21 (U/mg protein/min), $55.21(\mathrm{U} / \mathrm{mg}$ protein/min), respectively. Application of bioregulator significantly increased $(\mathrm{p} \leq 0.05)$ the SOD activity in both plants irrigated RW and SW. The results revealed that SOD activity in wheat plants irrigated SW exhibited markedly important changes by treated with foliar application of algae extracts. As compared with foliar application of oxalic acid bioregulator, algal extracts caused significant increase of SOD activity in wheat plants irrigated with SW.

POD, APX and CAT activities in wheat plants were also increased due to irrigation both $10 \%$ and $20 \%$ SW. 
Hanaa H. Abd El Baky et al. / American Journal of Agricultural and Biological Sciences 9 (2): 127-137, 2014

Table 3. Influences of Spirulina platensis and Scenedesmus obliquus extracts spraying on antioxidant compounds content of wheat levies irrigated by diluted sea water

\begin{tabular}{|c|c|c|c|c|c|c|c|c|c|c|c|c|c|}
\hline \multirow[b]{2}{*}{ Salinity } & \multirow[b]{2}{*}{ Treatments } & \multicolumn{4}{|c|}{ Carotenoids } & \multicolumn{4}{|c|}{ Tecopherols } & \multicolumn{4}{|c|}{ Ascorbic acid } \\
\hline & & $\begin{array}{r}\mathrm{mg} / \mathrm{g} \\
\text { F.W } \\
\end{array}$ & Ratio $^{a}$ & Ratio $^{\text {b }}$ & Ratio $^{c}$ & $\begin{array}{l}\mu \mathrm{mol} / \mathrm{g} \\
\text { F.W }\end{array}$ & Ratio $^{a}$ & Ratio $^{\text {b }}$ & Ratio $^{c}$ & $\begin{array}{l}\mu \mathrm{mol} / \mathrm{g} \\
\text { F.W }\end{array}$ & Ratio $^{a}$ & Ratio $^{\text {b }}$ & Ratio $^{c}$ \\
\hline \multirow[t]{4}{*}{ Tap water } & Negative control & 0.492 & 0.0 & & & 0.795 & 0.0 & & & 0.239 & 0.0 & & \\
\hline & Sp. & 0.580 & 1.2 & 0.933 & 0.8 & 1.650 & 2.1 & 1.7 & 1.0 & 0.452 & 1.9 & 1.3 & 0.8 \\
\hline & Sc. & 0.611 & 1.2 & 1.000 & 0.8 & 1.450 & 1.8 & 1.5 & 0.9 & 0.396 & 1.7 & 1.1 & 0.7 \\
\hline & $\begin{array}{l}\text { Positive control } \\
\text { (Oxalic acid) }\end{array}$ & 0.535 & 1.1 & 0.900 & 0.7 & 0.921 & 1.2 & 1.2 & 0.6 & 0.314 & 1.3 & 0.9 & 0.6 \\
\hline \multirow[t]{4}{*}{$10 \%$ sea water } & Negative control & 0.621 & 1.3 & 0.000 & & 0.974 & 1.2 & 0.0 & & 0.351 & 1.5 & 0.0 & \\
\hline & Sp. & 0.954 & 1.9 & 1.500 & 1.3 & 2.120 & 2.7 & 2.7 & 1.3 & 0.745 & 3.1 & 2.1 & 1.4 \\
\hline & Sc. & 0.921 & 1.9 & 1.500 & 1.3 & 1.930 & 2.4 & 2.0 & 1.2 & 0.651 & 2.7 & 1.9 & 1.2 \\
\hline & $\begin{array}{l}\text { Positive control } \\
\text { (Oxalic acid) }\end{array}$ & 0.871 & 1.8 & 1.400 & 1.2 & 1.210 & 1.5 & 1.5 & 0.7 & 0.523 & 2.2 & 1.5 & 1.0 \\
\hline \multirow[t]{4}{*}{$20 \%$ sea water } & Negative control & 0.731 & 1.5 & 1.200 & 0.0 & 1.620 & 2.0 & 1.7 & 0.0 & 0.532 & 2.2 & 1.5 & 0.0 \\
\hline & Sp. & 1.410 & 2.9 & 2.300 & 1.9 & 2.420 & 3.0 & 3.0 & 1.5 & 0.897 & 3.8 & 2.6 & 1.7 \\
\hline & sc. & 1.310 & 2.7 & 2.100 & 1.8 & 2.220 & 2.8 & 2.3 & 1.4 & 0.784 & 3.3 & 2.2 & 1.5 \\
\hline & $\begin{array}{l}\text { Positive control } \\
\text { (Oxalic acid) }\end{array}$ & 1.210 & 2.5 & 1.900 & 1.7 & 1.350 & 1.7 & 1.7 & 0.8 & 0.698 & 2.9 & 2.0 & 1.3 \\
\hline \multicolumn{2}{|c|}{ LSD at $(=<0.05)$} & \multicolumn{4}{|c|}{$\begin{array}{l}0.110 \\
\text { Phenolic }\end{array}$} & \multicolumn{2}{|l|}{0.090} & GSI & & \multicolumn{4}{|l|}{0.020} \\
\hline \multirow{5}{*}{$\begin{array}{l}\text { Salinity } \\
\text { Tap water }\end{array}$} & Treatments & $\begin{array}{l}\mathrm{mg} / \mathrm{g} \\
\text { F.W }\end{array}$ & \multicolumn{2}{|c|}{ Ratio $^{a}$} & Ratio $^{\mathrm{b}}$ & \multicolumn{2}{|c|}{ Ratio $^{\text {c }}$} & \multicolumn{2}{|c|}{$\begin{array}{c}\mu \mathrm{mol} / \mathrm{g} \\
\text { F.W }\end{array}$} & Ratio $^{a}$ & \multicolumn{2}{|c|}{ Ratio $^{\text {b }}$} & Ratio $^{c}$ \\
\hline & Negative control & 1.32 & \multicolumn{2}{|c|}{0.0} & & & & \multicolumn{2}{|c|}{0.392} & 0.0 & & \\
\hline & Sp. & 2.65 & \multirow{2}{*}{\multicolumn{2}{|c|}{2.0}} & 1.7 & \multicolumn{2}{|c|}{1.4} & \multicolumn{2}{|c|}{0.774} & 2.0 & \multicolumn{2}{|c|}{1.8} & 1.1 \\
\hline & Sc. & 1.98 & \multirow{2}{*}{\multicolumn{2}{|c|}{$\begin{array}{l}1.5 \\
1.03\end{array}$}} & 1.3 & \multicolumn{2}{|c|}{1.1} & \multicolumn{2}{|c|}{0.642} & 1.6 & \multicolumn{2}{|c|}{1.5} & 0.9 \\
\hline & $\begin{array}{l}\text { Positive control } \\
\text { (Oxalic acid) }\end{array}$ & 1.36 & & & 0.9 & 0.7 & & 0.52 & & 1.3 & 1.2 & & 0.8 \\
\hline $10 \%$ sea water & Negative control & 1.53 & 1. & & 0.0 & & & 0.42 & & 1.1 & 0.0 & & \\
\hline & Sp. & 1.97 & 1. & & 1.3 & 1.1 & & 0.97 & & 2.5 & 2.3 & & 1.4 \\
\hline & Sc. & 1.67 & 1. & & 1.1 & 0.9 & & 0.85 & & 2.3 & 2.1 & & 1.3 \\
\hline & $\begin{array}{l}\text { Positive control } \\
\text { (Oxalic acid) }\end{array}$ & 1.64 & 1. & & 1.1 & 0.9 & & 0.85 & & 2.2 & 2.0 & & 1.3 \\
\hline $20 \%$ sea water & Negative control & 1.86 & 1. & & 0.9 & 0.0 & & 0.68 & & 1.7 & 1.6 & & 0.0 \\
\hline & Sp. & 2.22 & 1. & & 1.5 & 1.2 & & 1.35 & & 3.4 & 3.2 & & 2.0 \\
\hline & Sc. & 1.99 & 1 . & & 1.3 & 1.1 & & 0.98 & & 2.5 & 2.3 & & 1.5 \\
\hline & $\begin{array}{l}\text { Positive control } \\
\text { (Oxalic acid) }\end{array}$ & 1.93 & 1 & & 1.3 & 1.0 & & 0.97 & & 2.5 & 2.3 & & 1.4 \\
\hline LSD at $(=<0.05)$ & & 0.30 & & & & & & 0.02 & & & & & \\
\hline
\end{tabular}

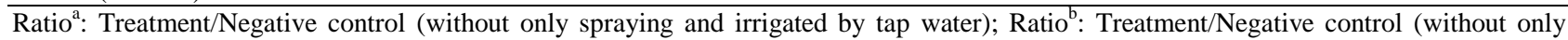
spraying and irrigated by $10 \%$ sea water); Ratio ${ }^{\mathrm{c}}$ : Treatment/Negative control (without only spraying and irrigated by $20 \%$ sea water)

However, the activities of POD, APX and CAT enzyme activities were higher in SW stress wheat plants treated with $S$. platensis than in $S$. obliquuss extract. Also, these activities were significantly increased in plant treated with oxalic acid. In general, the enzyme activities of SOD, POD, APX and CAT in wheat plants treated with algal extracts behaved completely similar trend with significant differences. Similar effect of algal extracts on activities of antioxidant enzymes (SOD, POD, APX and CAT) in wheat plants exposed to salt-stress here had already been observed in some plants treated with some bioregulatores. Looking at antioxidant constituents in algal and antioxidant activities of each enzyme, it is clear that the level of algal constituents caused significant differential role in controlling activities of antioxidant enzymes of wheat plants when irrigated SW, which ultimately resulted in differential response to salt stress.

\subsection{Effect of Algal Extracts on Lipid Peroxidation of wheat Plants Cultivation under Sea Water Stress}

In this study, lipid peroxidation was determined by TBARs content, which is one of the decomposition products of Polyunsaturated Fatty Acids (PUFA) of lipid membrane. 
Hanaa H. Abd El Baky et al. / American Journal of Agricultural and Biological Sciences 9 (2): 127-137, 2014

Table 4. Influences of Spirulina platensis and Scenedesmus obliquus extract spraying on antioxidant enzymes activities of wheat levies irrgated by diluted sea water

\begin{tabular}{|c|c|c|c|c|c|c|c|c|c|c|c|c|c|c|c|c|c|}
\hline \multirow[b]{2}{*}{ Salinity } & \multirow[b]{2}{*}{ Treatments } & \multicolumn{4}{|c|}{$\mathrm{U} / \mathrm{mg}$ protein $/ \mathrm{min}$} & \multicolumn{4}{|c|}{$\mathrm{U} / \mathrm{mg}$ protein $/ \mathrm{min}$} & \multicolumn{4}{|c|}{$\mathrm{U} / \mathrm{mg}$ protein $/ \mathrm{min}$} & \multicolumn{4}{|c|}{$\mathrm{U} / \mathrm{mg}$ of protein } \\
\hline & & SOD & Ratio $^{a}$ & Ratio $^{\text {b }}$ & Ratio $^{\mathrm{c}}$ & POD & Ratio $^{a}$ & Ratio $^{\text {b }}$ & Ratio $^{c}$ & APX & Ratio $^{a}$ & Ratio $^{\text {b }}$ & Ratio $^{c}$ & CAT & Ratio $^{a}$ & Ratio $^{\text {b }}$ & Ratio $^{\circ}$ \\
\hline \multirow[t]{4}{*}{ Tap water } & Negative control & 34.22 & 0.0 & & & 32.41 & 0.00 & & & 282.3 & 0.0 & & & 21.23 & 0.00 & 0.79 & 0.67 \\
\hline & Sp. & 48.74 & 1.4 & 1.2 & 1.0 & 39.15 & 1.20 & 1.0 & 0.9 & 375.2 & 1.3 & 1.2 & 1.1 & 26.33 & 1.24 & 0.95 & 0.83 \\
\hline & Sc. & 40.51 & 1.2 & 1.0 & 0.8 & 38.45 & 1.20 & 1.0 & 0.9 & 352.5 & 1.2 & 1.1 & 1.1 & 23.54 & 1.10 & 0.88 & 0.74 \\
\hline & $\begin{array}{l}\text { Positive control } \\
\text { (Oxalic acid) }\end{array}$ & 38.23 & 1.1 & 0.9 & 0.8 & 37.78 & 1.20 & 1.0 & 0.8 & 330.9 & 1.2 & 1.1 & 1.0 & 22.98 & 1.08 & 0.86 & 0.72 \\
\hline \multirow[t]{4}{*}{$10 \%$ sea water } & Negative control & 41.21 & 1.2 & 0.0 & & 39.23 & 1.20 & 0.0 & & 310.2 & 1.1 & 0.0 & & 26.65 & 1.25 & 0.00 & 0.84 \\
\hline & Sp. & 51.52 & 1.5 & 1.3 & 1.0 & 46.37 & 1.40 & 1.2 & 1.0 & 437.5 & 1.5 & 1.4 & 1.3 & 39.87 & 1.87 & 1.49 & 1.26 \\
\hline & Sc. & 49.31 & 1.4 & 1.2 & 1.0 & 45.32 & 1.40 & 1.2 & 1.0 & 391.4 & 1.4 & 1.3 & 1.2 & 32.98 & 1.55 & 1.23 & 1.04 \\
\hline & $\begin{array}{l}\text { Positive control } \\
\text { (Oxalic acid) }\end{array}$ & 45.72 & 1.3 & 1.1 & 0.9 & 43.25 & 1.30 & 1.1 & 1.0 & 369.2 & 1.3 & 1.2 & 1.1 & 29.76 & 1.40 & 1.11 & 0.93 \\
\hline \multirow[t]{5}{*}{$20 \%$ sea water } & Negative control & 49.23 & 1.4 & 1.2 & 0.0 & 45.25 & 1.40 & 1.2 & 0.0 & 335.2 & 1.2 & 1.1 & 0.0 & 31.65 & 1.49 & 1.19 & 0.00 \\
\hline & Sp. & 55.21 & 1.6 & 1.3 & 1.1 & 51.28 & 1.58 & 1.3 & 1.1 & 458.9 & 1.6 & 1.5 & 1.4 & 46.87 & 2.20 & 1.76 & 1.48 \\
\hline & sc. & 53.21 & 1.6 & 1.3 & 1.1 & 49.53 & 1.50 & 1.3 & 1.1 & 423.7 & 1.5 & 1.4 & 1.3 & 39.95 & 1.88 & 1.49 & 1.26 \\
\hline & $\begin{array}{l}\text { Positive control } \\
\text { (Oxalic acid) }\end{array}$ & 51.92 & 1.5 & 1.3 & 1.1 & 47.47 & 1.50 & 1.2 & 1.1 & 390.7 & 1.4 & 1.3 & 1.2 & 34.84 & 1.64 & 1.31 & 1.10 \\
\hline & & 2.35 & & & & 2.14 & & & & 8.54 & & & & 2.17 & & & \\
\hline
\end{tabular}

Ratio ${ }^{a}$ : Treatment/Negative control (without only spraying and irrigated by tap water); Ratio ${ }^{\text {b }}$ Treatment/Negative control (without only spraying and irrigated by $10 \%$ sea water); Ratio ${ }^{c}$ : Treatment/Negative control (without only spraying and irrigated by $20 \%$ sea water)

Table 5. Effect of Spirulina platensis and Scenedesmus obliquus extracts on lipid peroxidation in wheat plants irrigated with sea water

\begin{tabular}{llll}
\hline Salinity & Treatment & $\begin{array}{l}\text { TBARs } \\
\text { (MDA mmol/mg protein) }\end{array}$ & $\begin{array}{l}\text { Inhibition } \\
(\%)\end{array}$ \\
\hline Tap water & Tap water & $1.55 \pm 0.23$ & 88.87 \\
& Sp. & $3.56 \pm 0.22$ & 98.65 \\
& Sc. & $3.11 \pm 0.28$ & 94.63 \\
$10 \%$ sea water & (Oxalic acid) & $2.35 \pm 0.12$ & 90.21 \\
& 10\% sea water & $1.12 \pm 0.21$ & 54.65 \\
& Sp. & $3.01 \pm 0.23$ & 89.54 \\
$20 \%$ sea water & Sc. & $2.65 \pm 0.25$ & 83.87 \\
& (Oxalic acid) & $2.12 \pm 0.13$ & 78.74 \\
& 20\% sea water & $0.98 \pm 0.11$ & 45.32 \\
LSD at $(=<0.05)$ & Sp. & $2.87 \pm 0.22$ & 74.32 \\
& Sc. & $2.54 \pm 0.15$ & 67.87 \\
& (Oxalic acid) & $1.87 \pm 0.21$ & 55.86
\end{tabular}

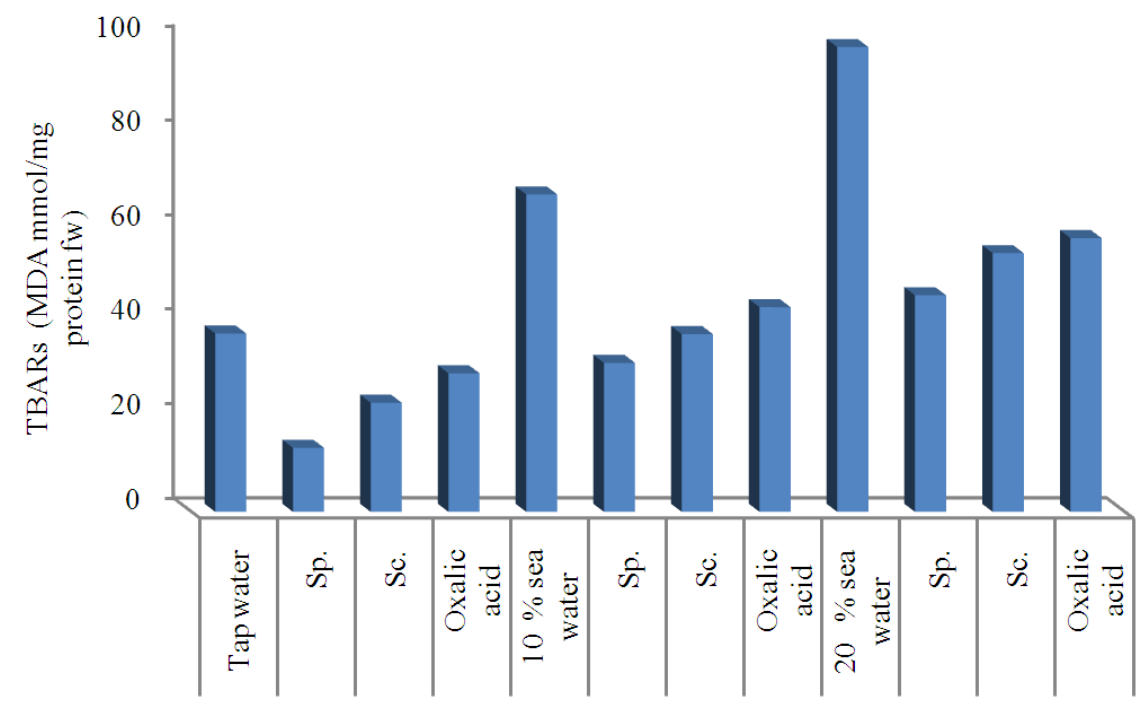

Fig. 1. Effect of Spirulina platensis and Scenedesmus obliquus extracts on lipid peroxidation in wheat plants irrigated with sea water 
Hanaa H. Abd El Baky et al. / American Journal of Agricultural and Biological Sciences 9 (2): 127-137, 2014

Table 6. Effect of Spirulina platensis and Scenedesmus obliquus extracts on dry weight and yield in wheat plants irrigated with sea water

\begin{tabular}{llll}
\hline Salinity & Treatment & $\begin{array}{l}\text { Whole plant dry weight } \\
(\mathrm{g})\end{array}$ & $\begin{array}{l}100 \text { grain weight } \\
(\mathrm{g})\end{array}$ \\
\hline Tap water & Negative control & $1.55 \pm 0.23$ & $3.45 \pm 0.16$ \\
& Sp. & $3.56 \pm 0.22$ & $4.35 \pm 0.16$ \\
& Sc. & $3.11 \pm 0.28$ & $4.11 \pm 0.21$ \\
& Positive control & $2.35 \pm 0.12$ & $3.87 \pm 0.24$ \\
& (Oxalic acid) & & $3.1 \pm 30.22$ \\
$10 \%$ sea water & Negative control & $1.12 \pm 0.21$ & $4.01 \pm 0.25$ \\
& Sp. & $3.01 \pm 0.23$ & $3.75 \pm 0.27$ \\
& Sc. & $2.65 \pm 0.25$ & $3.24 \pm 0.31$ \\
& Positive control & $2.12 \pm 0.13$ & $2.85 \pm 0.19$ \\
& (Oxalic acid) & & $3.83 \pm 0.17$ \\
& Negative control & $0.98 \pm 0.11$ & $3.08 \pm 0.22$ \\
& Sp. & $2.87 \pm 0.22$ & $2.76 \pm 0.32$ \\
SSD at $(=<0.05)$ & Sc. & $2.54 \pm 0.15$ & 0.15 \\
\hline
\end{tabular}

As shown in Table 5 and Fig. 1, the high level of TBARs in wheat plants irrigated with $10(67.23)$ and 20\% SW (98.45 MDA mmol/mg protein $\mathrm{fw}$ ) than that of plant irrigated RW (37.77 MDA mmol/mg protein $\mathrm{fw}$ ). Whereas, these levels were decreased significantly in plants treated with algal extracts of $S$. platensis $(31.56-$ 45.87) and $S$. obliquus (37.65-54.78 MDA mmol/mg protein fw) when compared with untreated plants. Generally, these results revealed that algal extracts induced protection action against oxidative damage caused by salt stress.

\subsection{Effect of Algal Extracts on Dry Weight and Grain Yield of wheat Plants Cultivation under Sea Water Stress}

The irrigation wheat plants with 10 and $20 \% \mathrm{SW}$ showed adverse effect on the overall growth parameters, that caused significant reduction of plant height, shoot fresh, spike length and spikelet's/spike (data not showed). Dry Weight (PDW) and Grain Yield (GY) of wheat plants irrigated RW were significantly reduced by $1.55 \mathrm{~g}$ and 3.45, respectively (Table 6). Treated wheat plant irrigated 10 and $20 \%$ SW with of S. platensis and S. obliquus algal extracts showed markedly significant increase of both PDW and GY, with values ranged (2.873.01 and 2.54-2.65 g) and (3.83-4.01g and 3.03-3.75g), respectively. The elevation in PDW and GY of treated plant with algal extracts may be due to their improvement in all growth parameter. Similar effect was noted in plant treated with oxalic acid, but it was less than that in plants treated with algal extracts.

\section{DISCUSSION}

Treated wheat plants with algae extract contained high amounts of antioxidant constituents was positive correlated with increasing of photosynthetic pigments restored in wheat plants irrigated SW. In other words, algal extracts might improve the salt tolerance of wheat plants by restoring the main photosynthetic pigments. Similar results were reported by Abd El Baky et al. (2010), those chlorophylls in photosynthetic membranes could be protected the photosynthetic apparatus from excessive ROS by quenching of singlet oxygen and other radicals.

Application of algal extracts increased the levels of phenolic compounds, ascorbic acid and $\alpha$-tocopherol, in wheat plants irrigated sea water to protect the membrane by preventing or reducing oxidative damage by ROS (Abd El Baky and El-Baroty, 2008). However, it is hypothesized a cycle where $\mathrm{H}_{2} \mathrm{O}_{2}$ scavenged by phenolic compounds to produce phenoxyl radicals, this radical reduces the ascorbic acid into mono $(\mathrm{OH})$ dehydroascorbate (Abd El Baky and El-Baroty, 2008).

It has been known that, salt stress leads an extensive lipid peroxidation, which is a good indicator of salt-induced oxidative damage at the cellular level (Hernandez and Almansa, 2002). Also, Elstner (1991) reported that salt stress causes an oxidative stress due to induction high amount of ROS in plants such as superoxides (-O2), Hydroxyl $(-\mathrm{OH})$ and peroxy radicals $(\mathrm{OOH})$.

Moreover, algae could improve protection defense in wheat plant with increase efficiency either through nonenzyme or enzyme antioxidative systems, as marker by increased antioxidant compounds (CAR, AA, GSH, TOC 
and phenolic) and higher activity of SOD, CAT, POX and POX and GR antioxidant enzymes. Similar results obtained with Abd El Baky et al. (2010), demonstrated that significant decrease in TBARs level in leaves of wheat plants grown under salt stress and treated with algal extracts rich in antioxidant compounds. In contrast, increased MDA content in wheat plants irrigated 10 and $20 \% \mathrm{SW}$ may indicate a higher oxidative damage due to inadequate response of the endogens antioxidative systems. In this respect, Hernandez et al. (2000) demonstrated that plants defend against reactive oxygen species by induction of certain antioxidative enzyme activities such as CAT, PEX, GR and SOD, which scavenge their reactive oxygen species. Also, Muthukumarasamy et al. (2000) and Rios-Gonzalez et al. (2002) stated that salt tolerance is often correlated with increasing the activity of antioxidative enzymes such as APX, GR and SOD, in wheat grown under sea water stress. The higher antioxidant enzyme activities of SOD, POD, APX, GR and GST were detected in tomato, barley, maize and sunflower plants grow under salt stress (Liang, 1999; Rodriguez-Rosales et al., 1999). Raza et al. (2007) reported that the salt tolerance in many plants is correlated with a more efficient antioxidative system.

In general, similar response of wheat plants to application both algal extracts of $S$. obliquue and $S$. platensis caused protective varied effect on wheat plant due to reduction of ROS levels with associated higher quantity of antioxidant compounds. Abd El Baky et al. (2012) reported that algal rich content of antioxidant is algal known to scavenge hydroxy radicals and other reactive oxygen species in plants exposed to salt stress and their effect coupled with elevation in the activities of all antioxidant enzymes.

However, low FW, DW and GY in wheat and barley plants irrigated SW has been reported in literature (Sairam and Srivastava, 2002; Francois et al., 1984). Abd El Baky et al., 2010) stated that improve of PDW and SY as one of the parameters of salt tolerance in wheat irrigated SW treated with algal extracts indicated that metabolic and photosynthetic processes was restored.

Here again, application of algal extracts seemed to reduce SW salinity stress of wheat plants by restored the photosynthetic pigments and increased the antioxidant defense abilities included non-enzymatic and enzymatic antioxidant systems, which led to reduce the oxidative damage of functional molecules and maintenance of many physiological processes of wheat plants such as photosynthetic activity and productivity (Abd El Baky et al., 2010).
Finally, the $S$. platensis and $S$. obliquus extracts could be contain some bioactive components act as growth regulator substances such as auxine and cytokinins, in additional to antioxidant compounds (Table 1) which lead to mitigate the effect of sea water salinity stress on wheat plant metabolic pathway. The results of Molnar and Ordog (2005) and Abd El Baky et al. (2010) reported that some plant growth regulators found in microalgae possessed beneficial effects on tissue cultures of recalcitrant plants.

\section{CONCLUTION}

The present results indicate that, treated wheat plants irrigated SW with $S$. platensis and $S$ obliquus extracts exhibited a protection action against oxidative stress induced by salt stress due to elevation the levels of nonantioxidant constituents and enzyme antioxidant protective systems. The later substances are known to be responsible for salt tolerance of wheat plants. Therefore, the irrigation of wheat plants by mean of brackish water at $20 \%(\mathrm{v} / \mathrm{v})$ is possible when treated with algal extracts.

\section{REFERENCES}

Abd El Baky, H.H. and G.S. El-Baroty, 2013a. Healthy benefit of microalgal bioactive substances. J. Aquatic Sci., 1: 11-23.

Abd El Baky, H.H. and G.S. El-Baroty, 2013b. The potential use of microalgal carotenoids as dietary supplements and natural preservative ingredient. J. Aquatic Food Product. Technol., 4: 392-406. DOI: 10.1080/10498850.2011.654381

Abd El Baky, H.H. F.K. El-Baz and G.S. El-Baroty, 2010. Enhancing antioxidant availability in wheat grains from plants grown under seawater stress in response to microalgae extract treatments. J. Sci. Food Agric., 90: 299-303. DOI: 10.1002/jsfa.3815

Abd El Baky, H.H., G.S. El-Baroty, A. Bouaid, M. Martinez and J. Aracil, 2012. Enhancement of lipid accumulation in Scenedesmus obliquus by Optimizing $\mathrm{CO}_{2}$ and $\mathrm{Fe}^{3+}$ levels for biodiesel production. Bioresource Technol., 119: 429-432. DOI: 10.1016/j.biortech.2012.05.104

Abd El Baky, H.H., M.M. Hussein and G.S. ElBaroty, 2008. Algal extracts improve antioxidant defense abilities and salt tolerance of wheat plant irrigated with sea water. Afr. J. Biochem. Res., 2: 151-164. 
Abd El-Baky, H.H. and G.S. El-Baroty, 2012. Characterization and bioactivity of phycocyanin isolated from Spirulina maxima grown under salt stress. Food Funct., 3: 381-388. DOI: 10.1039/C2FO10194G

Ali, A.A. and F. Alqurainy, 2006. Activities of Antioxidants in Plants under Environmental Stress. In: The Lutein-Prevention and Treatment for Diseases, Motohashi, N. (Ed.), Transworld Research Network, Trivandrum, ISBN-10: 817895219X, pp: 187-256.

Asada, K., 1999. The water-water cycle in chloroplasts: Scavenging of active oxygen and dissipation of excess photons. Annu. Rev. Plant Physiol. Plant Mol. Biol., 50: 601-639. DOI: 10.1146/annurev.arplant.50.1.601

Ashraf, M., 2010. Biotechnological approach of improving plant salt tolerance using antioxidants as markers. Biotechnol. Adv., 27: 84-93. PMID: 18950697

Ashraf, M., H.R. Athar, P.J.C. Harris and T.R. Kwon, 2008. Some prospective strategies for improving crop salt tolerance. Adv. Agron., 97: 45-110. DOI: 10.1016/S0065-2113(07)00002-8

Augustin, J., 1985. Methods of Vitamin Assay. 4th Edn., John Wiley and Sons, New York, ISBN-10: 0471869570, pp: 590.

Bradford, M.M., 1976. A rapid and sensitive method for the quantitation of microgram quantities of protein utilizing the principle of protein-dye binding. Anal. Biochem., 72: 248-258. DOI: 10.1016/00032697(76)90527-3

Chance, B. and A.C. Maehly, 1955. Assay of Catalase and Peroxidase. In: Methods of Enzymology, Colowic, S.P. and N.O. Kaplan (Eds.), Academic Press, New York, ISBN-10: 0121822737.

Elstner, E.F., 1991. Mechanisms of OXYGEN activation in Different Compartments of Plant Cell. In: Active Oxygen/Oxidative Stress and Plant Metabolism, Pell, E.J. and K.L. Stefen (Eds.), American Society of Plant Physiol., Rockville, MD, ISBN-10: 0943088224, pp: 13-25.

Francois, L.E., T. Donovan and E.V. Maas, 1984. Salinity effects on seed yield, growth and germination of grain sorghum. Agron. J., 76: 741-744. DOI: 10.2134/agronj1984.00021962007600050008x

Gill, S.S. and N. Tuteja, 2010. Reactive oxygen species and antioxidant machinery in abiotic stress tolerance in crop plants. Plant Physiol. Biochem., 48: 909930. DOI: 10.1016/j.plaphy.2010.08.016
Ginnopolitis, N.C. and S.K. Ries, 1977. Superoxide dismutase occurrence in higher plants. Plant Phys., 59: 309-314. DOI: 10.1104/pp.59.2.309

Gupta, M., A. Cuypers, J. Vangronsveld and H. Clijsters, 1999. Copper affects the enzymes of the ascorbateglutathione cycle and its related metabolites in the roots of Phaseolus vulgaris. Physiol. Plant, 106: 262-267. DOI: 10.1034/j.1399-3054.1999.106302.x

Haraguchi, H., H. Ishikawa and I. Kubo, 1997. Antioxidative action of diterpenoids from Podocarpus nagi. Planta Med., 63: 213-215. DOI: 10.1055/s-2006-957655

Hernandez, J., A. Jimenez, P. Mullineaux and F. Sevilla, 2000. Tolerance of pea (Pisum sativum L.) to longterm salt stress is associated with induction of antioxidant defences. Plant Cell Environ., 23: 853862. DOI: 10.1046/j.1365-3040.2000.00602.x

Hernandez, J.A. and M.S. Almansa, 2002. Short-term effects of salt stress on antioxidant systems and leaf water relations of pea leaves. Physiol. Plant, 115: 251-257. PMID: 12060243

Karpinski, S., H. Gabrys, A. Mateo, B. Karpinska and P.M. Mullineaux, 2003. Light perception in plant disease defence signalling. Curr. Opin. Plant Biol., 4: 390-396. DOI: 10.1016/S1369-5266(03)00061-X

Kiddle, G., G.M. Pastori, S. Bernard, C. Pignocchi and J. Antoniw et al., 2003. Effects of leaf ascorbate content on defense and photosynthesis gene expression in Arabidopsis thaliana. Antioxid. Redox Sign., 5: 3-32. DOI: 10.1089/152308603321223513

Laloi, D., M. Richard, J. Lecomte, M. Massot and J. Clobert, 2004. Multiple paternity in clutches of common lizard Lacerta vivipara: data from microsatellite markers. Mol. Ecol., 13: 719-723. DOI: 10.1046/j.1365-294X.2004.02102.x

Li, A.H., K. Cheng, C. Wong, F. King-Wai and C. Feng et al., 2007. Evaluation of antioxidant capacity and total phenolic content of different fractions of selected microalgae. Food Chem., 102: 771-776. DOI: 10.1016/j.foodchem.2006.06.022

Liang, Y.C., 1999. Effects of silicon on enzyme activity and sodium, potassium and calcium concentration in barley under salt stress. Plant Soil, 209: 217-224. DOI: 10.1023/A:1004526604913

Lichtenthaler, H.K., 1987. Chlorophylls and carotenoids: Pigments of photosynthetic biomembranes. Meth. Enzymol., 147: 350-382. DOI: 10.1016/00766879(87)48036-1 
Molnar, Z. and V. Ordog, 2005. Microalgal and cyanobacterial extracts in the tissue culture of higher plants (pea, tobacco, beet). Acta Biol. Szegediensis, 49: 39-40.

Muthukumarasamy, M., S.D. Gupta and R. Pannerselvam, 2000. Enhancement of peroxidase, polyphenol oxidase and superoxide dismutase activities by triadimefon in $\mathrm{NaCl}$ stressed Raphanus sativus L. Biol. Plant., 43: 317-320. DOI: 10.1023/A:1002741302485

Nakano, M. and K. Asada, 1981. Hydrogen peroxide is scavenged by ascorbate-specific peroxidase in spinach chloroplasts. Plant Cell Physiol., 22: 867880.

Ordog, V., W.A. Stirk, J. Van Staden, O. Novk and M. Strnad, 2004. Endogenous cytokinins in three genera of microalgae from the Chlorophyta. J. Phycol., 40: 88-95. DOI: 10.1046/j.15298817.2004.03046.X

Pei, Z.M., Y. Mutrata, G. Benning, S. Thomine and B. Kiusener et al., 2000. Calcium channels activated by hydrogen peroxide mediate abscisic acid signalling in guard cells. Nature, 406: 731-734. PMID: 10963598

Polle, A., 2001. Dissecting the superoxide dismutaseascorbate-glutathione-pathway in chloroplasts by metabolic modeling. Computer simulations as a step towards flux analysis. Plant Physiol., 126: 445-462. DOI: $10.1104 /$ pp.126.1.445

Raza, S.H., H.R. Athar, M. Ashraf and A. Hameed, 2007. Glycinebetaine-induced modulation of antioxidant enzymes activities and ion accumulation in two wheat cultivars differing in salt tolerance. Environ. Exp. Bot., 3: 368-376. DOI: 10.1016/j.envexpbot.2006.12.009

Rios-Gonzalez, K., L. Erdei and S.H. Lips, 2002. The activity of antioxidant enzymes in maize and sunflower seedlings as affected by salinity and different nitrogen sources. Plant Sci., 162: 923-930. DOI: 10.1016/S0168-9452(02)00040-7
Rodriguez-Rosales, M.P., L. Kerkeb, P. Bueno and J.P. Donaire, 1999. Changes induced by $\mathrm{NaCl}$ in lipid content and composition, lipoxygenase, plasma membrane $\mathrm{H}^{+}$-ATPase and antioxidant enzyme activities of tomato (Lycopersicon esculentum. Mill) calli. Plant Sci., 143: 143-150. DOI: 10.1016/S01689452(99)00046-1

Sairam, R.K. and G.C. Srivastava, 2002. Changes in antioxidant activity in sub-cellular fractions of tolerant and susceptible wheat genotypes in response to long term salt stress. Plant Sci., 162: 897-904. DOI: 10.1016/S0168-9452(02)00037-7

Schafer, M.K., H. Varoqui, N. Defamie, E. Weihe and J.D. Erickson, 2002. Molecular cloning and functional identification of mouse vesicular glutamate transporter 3 and its expression in subsets of novel excitatory neurons. J. Biol. Chem., 277: 50734-50748. DOI: 10.1074/jbc.M206738200

Semeneko, V.E. and A.A. Abdullaev, 1980. Parametric control of beta-carotene biosynthesis in Dunaliella salina cells under conditions of intensive cultivation. Soviet Plant Physiol., 27: 31-41.

Silber, R., M. Farber, E. Papopoulos, D. Nervla and L. Liebes et al., 1992. Glutathione depletion in chronic lymphocytic leukemia $\alpha$-lymphocytes. Blood, 80 : 2038-2040. PMID: 1356514

Snedecor, G.W. and W.G. Cochran, 1989. Statistical Methods. 1st Edn., Iowa State University Press, Ames, ISBN-10: 0813815614, pp: 503.

Tausz, M., A. Wonisch, M. Muller and D. Grill, 2000. The role of glutathione in the development of stress and damage to plants. Land Bauforsch Vlk Sonderheft, 218: 101-104.

Thajuddin, N. and G. Subramanin, 2005. Cyanobacterial biodiversity and potential applications in biotechnology. Curr. Sci., 89: 47-57.

Turhan, I, N. Tetik, M. Karhan, F. Gurel and H.R. Tavukcuoglu, 2008. Quality of honeys influenced by thermal treatment. LWT-Food Sci. Technol., 41: 1396-1399. DOI: 10.1016/j.lwt.2007.09.008 